AperTO - Archivio Istituzionale Open Access dell'Università di Torino

\title{
Verisimilitude and belief change for nomic conjunctive theories
}

\section{This is the author's manuscript}

Original Citation:

Availability:

This version is available http://hdl.handle.net/2318/144156

since 2016-04-06T07:15:16Z

Published version:

DOI:10.1007/s11229-012-0165-0

Terms of use:

Open Access

Anyone can freely access the full text of works made available as "Open Access". Works made available under a Creative Commons license can be used according to the terms and conditions of said license. Use of all other works requires consent of the right holder (author or publisher) if not exempted from copyright protection by the applicable law. 


\title{
Verisimilitude and belief change for nomic conjunctive theories
}

\author{
Gustavo Cevolani · Roberto Festa • \\ Theo A. F. Kuipers
}

Received: 8 May 2011 / Accepted: 30 July 2012 / Published online: 8 September 2012

(C) Springer Science+Business Media B.V. 2012

\begin{abstract}
In this paper, we address the problem of truth approximation through theory change, asking whether revising our theories by newly acquired data leads us closer to the truth about a given domain. More particularly, we focus on "nomic conjunctive theories", i.e., theories expressed as conjunctions of logically independent statements concerning the physical or, more generally, nomic possibilities and impossibilities of the domain under inquiry. We define both a comparative and a quantitative notion of the verisimilitude of such theories, and identify suitable conditions concerning the (partial) correctness of acquired data, under which revising our theories by data leads us closer to "the nomic truth", construed as the target of scientific inquiry. We conclude by indicating some further developments, generalizations, and open issues arising from our results.
\end{abstract}

Keywords Nomic verisimilitude · Truthlikeness · Truth approximation · Belief change $\cdot$ Belief revision $\cdot$ AGM

The intuitive idea underlying the notion of verisimilitude can be expressed as follows: a theory is highly verisimilar, or "close to the whole truth", if it says many things about the domain under investigation and many of those things are (almost) exactly true. The first formal definition of verisimilitude was proposed by Popper (1963).

\footnotetext{
G. Cevolani $(\varangle)$

University of Bologna, Bologna, Italy

e-mail: g.cevolani@gmail.com

R. Festa

University of Trieste, Trieste, Italy

T. A. F. Kuipers

University of Groningen, Groningen, The Netherlands
} 